\title{
Enumerating nucleoid-visible marine bacterioplankton: bacterial abundance determined after storage of formalin fixed samples agrees with isopropanol rinsing method
}

\author{
Jan H. Vosjan*, Govert J. van Noort \\ Department of Biological Oceanography, Netherlands Institute for Sea Research (NIOZ), PO Box 59, 1790 AB Den Burg, \\ Texel, The Netherlands
}

\begin{abstract}
The effect of storage of formalin-fixed sea water samples on bacterial abundance determined by DAPI staining and epifluorescence microscopy was compared with the abundance of nucleoid-visible bacteria using isopropanol rinsing after DAPI staining to remove non-specific staining of DAPI. While storage of formalin-fixed water samples at $4^{\circ} \mathrm{C}$ for 7 mo caused total bacterial numbers to decline exponentially until 50 to $70 \mathrm{~d}$, after which they remained stable, storage of sea water had no effect on the number of nucleoid-visible bacteria over a 7 mo period. Extrapolating the bacterial growth curve of nutrient amended sea water cultures by regression analysis to $t_{0}$ resulted in a number of active bacterial cells similar to that obtained by isopropanol rinsing of DAPI-stained samples. This might indicate that the lag phase commonly detected in sea water cultures is caused by the dominance of inactive bacteria at the time of inoculation. An intensive field study in the Dutch Wadden Sea showed that the number of nucleoid-visible bacteria continuously declined from around $100 \%$ of the total bacterial abundance at the end of the phytoplankton bloom to $75 \%$ within $2.5 \mathrm{mo}$. Again a strong correlation was detected between nucleoid-visible bacteria determined by DAPI staining and subsequent isopropanol rinsing and total bacterial abundance detectable in the formalin-fixed sea water samples after 7 mo of storage. Although the exact mechanism of the loss of 'non-nucleoid-visible cells' during sample storage remains unclear, the excellent agreement between the 2 methods indicates that DAPI-stained samples enumerated immediately and after a prolonged storage might be an alternative approach to determine the total bacterial abundance and the number of nucleoid-visible bacteria.
\end{abstract}

KEY WORDS: Bacterioplankton - Enumeration - Active bacteria $\cdot$ Epifluorescence microscopy $\cdot$ Preservation - Fixation

\section{INTRODUCTION}

Enumeration of nucleoid-stained bacterioplankton under the epifluorescence microscope (Zimmermann \& Meyer-Reil 1974) has led to altered views on the food web structure in the ocean and stimulated research on the role of bacterioplankton in the sea over the last 2 decades. This was largely due to the notion that bacterioplankton enumerated under the epifluorescence microscope are 2 to 4 orders of magnitude more abundant than when using the traditional plate counting

\footnotetext{
•E-mail: vosjan@nioz.n]
}

technique. By determining bacterioplankton abundance and activity it became obvious that bacterioplankton play an active role in aquatic food webs rather than being simply a terminal remineralisation component. This change in our view of the position of bacterioplankton in the food web led to the formulation of the microbial loop hypothesis (Azam et al. 1983).

The abundance of bacterioplankton is routinely determined by staining the nucleoid either by acridine orange or by $4^{\prime}, 6$-diamidino-2-phenylindole (DAPI) (Hobbie et al. 1977, Porter \& Feig 1980). However, as has been shown by autoradiography, only a fraction of the bacterioplankton community is active at a given 
time (Hoppe 1977, 1978, Zimmermann et al. 1978). Other techniques based on the redox dyes 2 -(p-iodophenyl)3-(p-nitrophenyl)-5-phenyl tetrazolium chloride (INT) and the recently introduced 5-cyano-2,3,-ditolyl tetrazolium chloride (CTC) also confirm the notion that only a fraction of the bacterial community is metabolically active (Tabor \& Neihof 1982, Porter et al. 1995, Pyle et al. 1995, Posch et al. 1997). Zweifel \& Hagström (1995) found that rinsing of DAPI-stained samples with isopropanol removes the non-specifically bound DAPI from cell material and makes the DNA-containing nucleoids clearly visible. These authors conclude that only between 2 and $32 \%$ of the bacterioplankton contain DNA, leaving a major fraction of the bacterial cells without any visible DNA. This observation has been challenged recently by Choi et al. (1996) who were able to culture these 'non-nucleoid-visible' bacteria; from their results they conclude that bacteria might have DNA dispersed in the cells during periods of low activity and therefore, the fluorescence of the DAPIstained DNA is too low to be detectable under the microscope

Turley \& Hughes (1992) report that the number of bacteria detectable after DAPI staining under the epifluorescence microscope decreases between 7 and $75 \%$ in seawater samples within a $40 \mathrm{~d}$ period. Therefore, they recommended staining and filtering the samples immediately after collection and storing the samples mounted on the slides at $-20^{\circ} \mathrm{C}$ to avoid loss in bacteria (Turley \& Hughes 1994). The reason for this bacterial loss in formalin- or glutaraldehyde-fixed samples during storage remains obscure. Recently, Gundersen et al. (1996) confirmed the findings of Turley \& Hughes (1992) and suggested that remaining protease activity in glutaraldehyde-preserved samples may be a major cause of this bacterial loss.

In this paper we tested the hypothesis that the loss of bacteria over time in formalin-fixed sea water samples stored at $4^{\circ} \mathrm{C}$ is caused by the loss or degradation of the non-nucleoid-visible bacteria. Therefore, we followed the decline of bacterial abundance during storage in formalin-fixed sea water samples collected from a range of different environments and ecological conditions (during a phytoplankton bloom and in a microcosin amended with nutrients) and compared this decline with the number of nucleoid-visible bacteria.

\section{MATERIAL AND METHODS}

Efiect of storage period on total bacterial counts and on the number of nucleoid-visible bacteria. North Sea water was collected in a cleaned $(0.1 \mathrm{~N} \mathrm{HCl}$ and rinsed 2 times with sample water) 1 l glass bottle in the
Marsdiep from the NIOZ pier (Dutch Wadden Sea) from $\sim 0.5 \mathrm{~m}$ depth. In the laboratory, $10 \mathrm{ml}$ of the water was fixed with formaldehyde ( $2 \%$ final conc.), stained as described below and immediately counted to determine the number of total and nucleoid-visible bacteria Thereafter, $100 \mathrm{ml}$ of formalin-fixed sea water was stored in the dark at $4^{\circ} \mathrm{C}$. At varying time intervals, subsamples were taken, brought to room temperature and the number of total and nucleoid-visible bacteria determined again.

Sea water cultures amended with nutrients. Two sets of experiments were performed. In the first experiment, $1 \mathrm{l}$ of sea water collected from the Marsdiep was filtered through a $1.0 \mu \mathrm{m}$ filter (Nuclepore) to remove protists and algae. In order to promote bacterial growth, the sea water was enriched with organic carbon (glucose:pyruvate:acetate $=1: 1: 1$, final conc. $1 \mathrm{mg}$ $\mathrm{C}^{-1}$ ), nitrate (final conc. $10 \mu \mathrm{M}$ ) and phosphate (final conc. $1 \mu \mathrm{M})$. The development of the abundance of total and nucleoid-visible bacteria was followed over an incubation period of $56 \mathrm{~h}$. The sea water culture was held in the dark at $20^{\circ} \mathrm{C}$. In the second experiment, sea water was collected during the OMEX cruise in the Celtic Sea in September 1995. This water was filtered through a $1.0 \mu \mathrm{m}$ filter (Nuclepore) and amended with nutrients as described for the first experiment. The sea water culture was held in the dark at in situ temperature for a total period of $56 \mathrm{~h}$ and sampled at varying intervals for total bacterial counts and nucleoid-visible bacteria. At each sampling, $20 \mathrm{ml}$ of formalin-fixed samples ( $2 \%$ final conc.) was taken additionally, stored at $4^{\circ} \mathrm{C}$ and the total bacterial abundance enumerated again after $10 \mathrm{wk}$ of storage in the dark at $4^{\circ} \mathrm{C}$.

Development of total and nucleoid-visible bacteria during the spring phytoplankton bloom. Water samples were collected in $1 \mathrm{l}$ cleaned glass bottles from the NIOZ pier during high water. Samples were immediately fixed with formalin ( $2 \%$ final conc.) and total bacterial abundance enumerated after DAPI staining and the nucleoid-visible bacteria after the additional isopropanol wash. The formalin-fixed samples (20 $\mathrm{ml}$ ) were subsequently stored at $4^{\circ} \mathrm{C}$ for 7 mo and thereafter the total number of bacteria enumerated again and compared with the number of nucleoid-visible bacteria.

Preparation for total bacterial counts. To $4 \mathrm{ml}$ of the formalin-fixed sea water ( $2 \%$ final conc.), $1 \mathrm{ml}$ of a DAPI solution in Mcllvaine buffer (final conc. of DAPI $2 \mu \mathrm{g} \mathrm{ml}^{-1}$ ) and $0.1 \mathrm{ml}$ of a $1 \%$ Triton $\mathrm{X}-100$ solution were added and incubated in the dark at room temperature for 1.5 to $2 \mathrm{~h}$. Thereafter the sample was filtered onto a $0.2 \mu \mathrm{m}$ pore-size black polycarbonate filter (Nuclepore, $25 \mathrm{~mm}$ filter diameter). To ensure even distribution of the bacteria, the polycarbonate filter was supported by a cellulose nitrate filter (Millipore, 


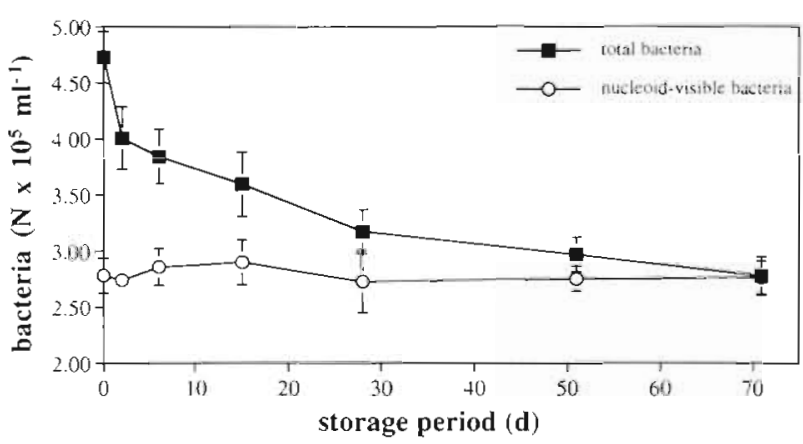

Fig. 1. Effect of sample storage on the abundance of total and nucleoid-visible bacteria. Means \pm SD of triplicate determinations

$0.45 \mu \mathrm{m}$ pore size). After filtration, the filter was washed with $4 \mathrm{ml}$ McIlvaine buffer and mounted on a slide. The total bacterial abundance was enumerated by epifluorescence microscopy (Zeiss, Axioplan) at $1250 \times$ magnification. At least 200 bacteria per sample were counted.

Preparation for enumerating nucleoid-visible bacteria. The protocol of Zweifel \& Hagström (1995) was slightly modified. The salinity of the sample was lowered from 34 to 27 psu due to the added reagents. Lowering the salinity to 10 psu did not influence the counting; however, the samples should be fixed with formalin to avoid swelling of the cells (see also Choi et al. 1996). After the DAPI and Triton X-100 addition to the sea water sample the bacteria were stained (as described above). Afterwards the filter with the DAPIstained bacteria was washed for $10 \mathrm{~min}$ by adding $3 \mathrm{ml}$ isopropanol (analytical grade), and then this isopropanol was sucked through the filter by applying a maximum vacuum of $100 \mathrm{~mm} \mathrm{Hg}$. After the isopropanol was removed, the filter was washed with $4 \mathrm{ml}$ McIlvaine buffer. Then, the filter was mounted on a slide and the number of nucleoid-visible bacteria determined under the epifluorescence microscope as described above.

\section{RESULTS}

\section{Effect of sample storage on the abundance of total and nucleoid-visible bacteria}

As shown in Fig. 1, storage of the formalin-fixed sea water at $4^{\circ} \mathrm{C}$ in the dark resulted in an exponential decline in the abundance of total bacteria. More than $30 \%$ of the initial total bacterial abundance was lost within $40 \mathrm{~d}$, while storage of the sea water had no effect on the abundance of nucleoid-visible bacteria (Fig. 1). Total bacterial counts reached similar levels as nucleoid-visible bacteria after $\sim 50 \mathrm{~d}$.

\section{Comparison between the number of actively growing bacteria derived by extrapolation from the exponential growth curve and the number of nucleoid-visible bacteria at the beginning of the experiment}

In sea water cultures with water collected in the Celtic Sea and amended with nutrients, bacteria responded to nutrient addition with an exponential increase in total bacterial number, initially $1.23 \times 10^{6}$ cells $\mathrm{ml}^{-1}$, and after a lag phase of about $20 \mathrm{~h}$ (Fig. 2). Applying linear regression analysis on the increase in naturallog-transformed total bacterial numbers over time, we are able to estimate the abundance of actively growing cells at the beginning of the incubation. As shown in Fig. 2, the abundance of active bacteria at $t_{0}$ was $1.12 \times$ $10^{5}$ cells $\mathrm{ml}^{-1}$, corresponding to $15 \%$ of the initial total bacterial abundance (Fig. 2, Table 1). The abundance of active bacteria obtained by extrapolating from the exponential growth curve to $t_{0}$ was remarkably similar to the number of nucleoid-visible bacteria at $t_{0}(1.74 \times$ $10^{5} \mathrm{ml}^{-1}$; Fig. 2, Table 1).

Similarly, in experiments performed with Wadden Sea water collected of the NIOZ pier, the number of active bacteria extrapolated from the growth curve to $t_{0}$ agreed well with the number of nucleoid-visible bac-

Table 1. Comparison of 4 sets of bacterial numbers from 3 independent sea water samples, 2 from the Celtic Sea and 1 from the Wadden Sea. Bacterial numbers: total number of bacteria counted immediately after sampling; number of actively growing bacteria derived by extrapolation to time 0 from the exponential growth curve of the nutrient amended sea water samples; total bacterial counts from the same formalin-fixed samples after storage for $10 \mathrm{wk}$; and nucleoid-visible bacteria counted in the formalinfixed samples after storage for $10 \mathrm{wk}$. Last column shows \% total bacterial counts (TBC) counted after $10 \mathrm{wk}$; for this, the TBC counted immediately after sampling is taken as $100 \%$. Bacterial numbers are given in $10^{6} \mathrm{ml}^{-1} \pm \mathrm{SD}$ of triplicate determinations

\begin{tabular}{|lccccr|}
\hline Location & Total bacteria & $\begin{array}{c}\text { Active bacteria } \\
\text { extrapolated }\end{array}$ & $\begin{array}{c}\text { Total bacteria } \\
\text { counted after 10 wk }\end{array}$ & $\begin{array}{c}\text { Nucleoid-visible bacteria } \\
\text { counted after 10 wk }\end{array}$ & $\begin{array}{c}\% \text { of bacteria counted } \\
\text { after } 10 \mathrm{wk}\end{array}$ \\
\hline Celtic Sea & $1.23 \pm 0.080$ & 0.11 & $0.17 \pm 0.013$ & $0.18 \pm 0.001$ & 15 \\
Celtic Sea & $2.32 \pm 0.209$ & 1.12 & $1.08 \pm 0.043$ & $1.08 \pm 0.076$ & 47 \\
Wadden Sea & $1.53 \pm 0.245$ & 1.52 & $1.53 \pm 0.245$ & $1.54 \pm 0.200$ & 100 \\
\hline
\end{tabular}




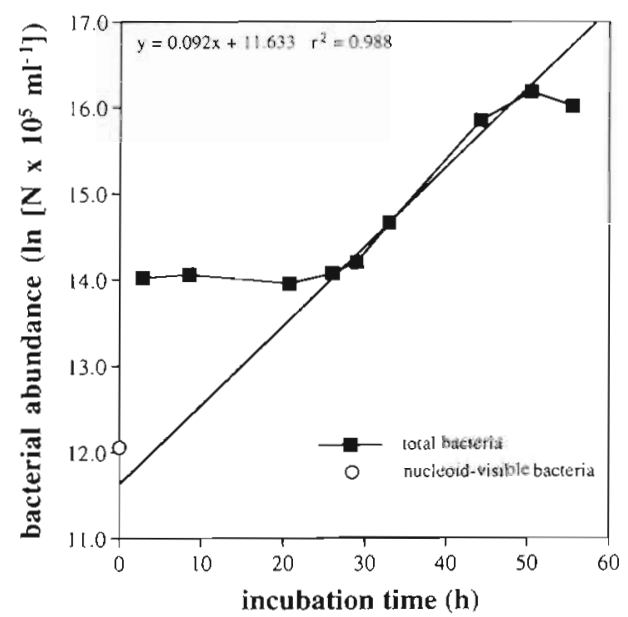

Fig. 2. Comparison between the number of actively growing bacteria derived by extrapolation from the natural-logtransformed bacterial abundance during exponential growth (between 26 and $50 \mathrm{~h}$ ) and the number of nucleoid-visible bacteria at the beginning of the experiment. Sea water was collected from the Celtic Sea and amended with nutrients

teria counted at $t_{0}$ (Table 1). Moreover, the number of active bacteria obtained by these 2 independent methods was similar to the total bacterial counts in formalin-fixed sea water samples after a storage period of 10 wk (Table 1). Therefore, all 3 methods resulted in similar numbers of active bacteria. The percentage of active bacteria varied between 15 and $47 \%$ in the Celtic Sea and $100 \%$ in the Wadden Sea. The Wadden Sea experiment was performed at the end of an intensive phytoplankton bloom (see also Fig. 3).

\section{Development of total and nucleoid-visible bacteria during the spring phytoplankton bloom and the relation between nucleoid-visible and total bacteria counted after 7 mo of storage}

In the Marsdiep area of the Wadden Sea, phytoplankton primary production increases (with many short-term variations) from mid-March to a maximum in May (Cadée \& Hegeman 1979). During the wane of the spring phytoplankton bloom in 1996, total bacterial abundance increased from about $1.5 \times 10^{6}$ to $12.5 \times$ $10^{6} \mathrm{ml}^{-1}$ within a period of $2.5 \mathrm{mo}$ (Fig. 3a). At the beginning of the intensive sampling period, the number of nucleoid-visible bacteria was similar to the total bacterial abundance; the percentage of nucleoidvisible bacteria continuously declined during the course of the sampling from initially $100 \%$ to around $75 \%$ of the total bacterial abundance (Fig. 3b). As indicated in Fig. 3a, the total bacterial number counted again after 7 mo of storage of the formalin-fixed sea water corre- sponded closely to that of nucleoid-visible bacteria counted immediately after the samples were taken. A highly significant correlation between the number of nucleoid-visible bacteria and the total bacterial abundance enumerated after 7 mo of storage was obtained for a bacterial abundance fluctuating over 1 order of magnitude (Fig. 4).

\section{DISCUSSION}

Turley \& Hughes (1992) detected a rapid decrease over time in bacterial abundance of DAPI-stained samples and, therefore, they recommended preparing and counting the samples immediately after collection or storing the filters mounted on the slides frozen. In a recent paper, Gundersen et al. (1996) suggested that protease activity is responsible for this decline in cell numbers during storage of formalin-fixed sea water. In
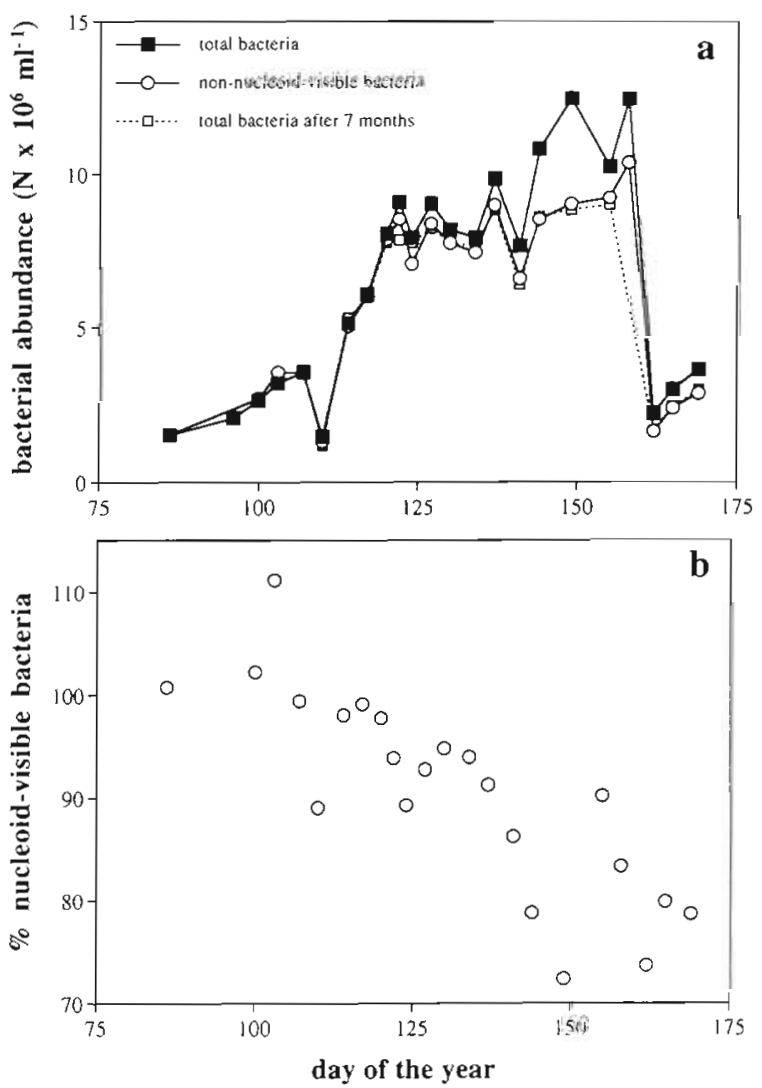

Fig. 3. (a) Development of total and nucleoid-visible bacteria during the wane of the spring phytoplankton bloom counted immediately after sampling and the number of total bacteria determined after a $?$ mo storage of the formalin-fixed sea water. (b) Day of the year vs percentage of nucleoid-visible bacteria in the total bacterial counts. There was a decrease in percentage nucleoid-visible bacteria during the wane of the phytoplankton bloom 


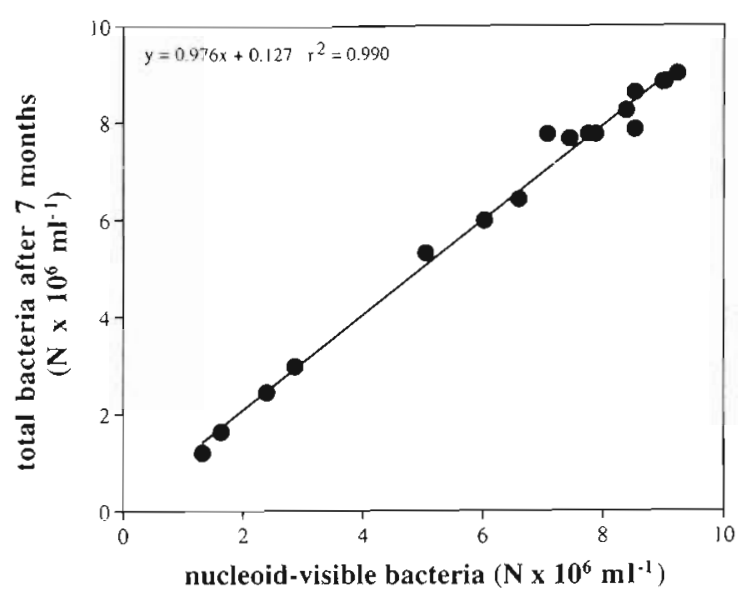

Fig. 4. Relation between the number of nucleoid-visible bacteria counted immediately after sampling and the total bacterial abundance counted in formalin-fixed sea water samples after a storage period of $7 \mathrm{mo}$

the present study, we noticed an exponential decline in the total bacterial numbers over time which levelled off in samples held at $4^{\circ} \mathrm{C}$ after around $40 \mathrm{~d}$. Storing the formalin-fixed samples for more than $40 \mathrm{~d}$ resulted in similar total bacterial counts to those of the nucleoidvisible bacteria using a slightly modified method of Zweifel \& Hagström (1995). This indicates that the non-nucleoid-visible cells deteriorate with time. In isopropanol-washed samples the nucleoid is clearly visible; the number of nucleoid-visible bacteria does not change during storage (Fig. 1), indicating no degradation of the nucleoid-visible bacteria during storage. If the assumption of Gundersen et al. (1996) is true that protease activity is responsible for the loss in bacterial abundance in formalin-fixed samples, then nonnucleoid-visible cells are most affected by protease activity. Protease, however, should act on both nucleoid and non-nucleoid cells. Thus, it is likely that non-nucleoid-visible bacteria are the result of autolysis of bacteria which continues after formalin fixation.

Fig. 2 shows a typical growth curve of natural bacterial communities held in batch culture with a lag phase, a phase of exponential growth and a stationary phase. The lag phase has been interpreted as an adaptation phase of natural bacterial communities to changing nutrient conditions (Ammerman et al. 1984) although radioactive tracer techniques such as thymidine or leucine incorporation do not indicate such a delay in activity. An alternative explanation for the presence of a lag phase is that a major fraction of the bacterial community stained with DAPI is in a nongrowing stage and that a significant increase in the total bacterial abundance can only be detected if the originally small fraction of actively growing cells are becoming the dominant fraction within the bacterial community. If this assumption is true, then the intercept with the $y$-axis of the linear regression of the natural-log-transformed bacterial abundance during the phase of logarithmic growth should provide an estimate of the number of actively growing bacteria at $t_{0}$ (Fig. 2, Table 1). Using this method, we obtained similar numbers of active bacteria to those obtained with the isopropanol rinsing method (Table 1). Moreover, these 2 estimates correspond well with the number of total bacteria detectable after $10 \mathrm{wk}$ of storage (Table 1), indicating that storage of sea water and bacterial counting after $>40 \mathrm{~d}$ of storage reflects the number of nucleiod-visible bacteria as shown also by the close correlation of both methods (Fig. 4).

The number of nucleoid-visible bacteria depends on the ecological condition of the water body. During the peak in spring phytoplankton bloom, the number of total bacteria and the nucleoid-visible bacteria increased sharply (Fig. 3a). Concomitant with this increase, the percentage of nucleoid-visible bacteria declined from 100 to $\sim 75 \%$ of the total bacterial community detected by conventional DAPI staining (Fig. 3b). For the 2 independent Celtic Sea water samples, 15 and $47 \%$ of the bacteria contained a nucleoid (Table 1). A wide range of values for active bacteria are reported in the literature, ranging from 2 to $80 \%$ using microautoradiography (Meyer-Reil 1978, Douglas et al. 1987, Grossmann 1994). Recently, Karner \& Fuhrman (1997) compared different methods to determine the percentage of active bacteria and concluded that $16 \mathrm{~S}$ rRNA universal probe counts were in good agreement with microautoradiography counts (on average, 56 and $49 \%$ of the total bacteria detected by DAPI staining, respectively) while the number of nucleoid-visible bacteria was somewhat lower (29\% of the total DAPIstainable bacteria). However, these authors as well as the original protocol of Zweifel \& Hagström (1995) did not use formalin fixation, while in the study of Choi et al. (1996) and this paper, formalin fixation was applied. Clearly, more investigations need to be done on this subject before final conclusions can be drawn. From this and from other studies, it is evident that a significant fraction of the total bacterial community might be inactive at a given time although this has to be stated with caution since Choi et al. (1996) were able to culture 'non-nucleoid-visible bacteria'. These authors found that 'non-nucleoid-visible bacteria' developed visible nucleoids prior to measurable increase in cell number. Using transmission electron microscopy, Heissenberger et al. (1996) showed that around $30 \%$ of the free-living bacteria had an at least partly degraded cytoplasm or had only the cell membrane remaining. These partly degraded bacteria could originate from autolysis of bacteria or be the remnants of flagellate grazing or viral lysis. 
In summary, we have shown that isopropanol rinsing of DAPI-stained bacteria gives results essentially identical to conventional DAPI counting after the formalinfixed sea water samples have been stored at $4^{\circ} \mathrm{C}$ in the dark for more than $40 \mathrm{~d}$. Thus DAPI staining and counting the samples immediately and after a storage period of $>40 \mathrm{~d}$ appears to be an alternative approach to distinguish between total bacterial abundance and nucleoid-visible bacteria. Further investigations are needed, however, to decipher whether these bacteria are really metabolically active at the time of sampling.

Acknowledgements. We are grateful to B. R. Kuipers for all the help and stimulating discussions and G. J. Herndl for reformulating an earlier version of the manuscript. The comments of 3 reviewers helped to improve the manuscript. G. C. Cadée and J. Hegeman are acknowledged for taking the Wadden Sea samples. Financial support of this study was provided by the EU-MAST II program (OMEX-1 project, contract no. MAS-2-CT93-0069) and by the Netherlands Foundation GOA. This is contribution no. 3231 of NIOZ.

\section{LITERATURE CITED}

Ammerman JW, Fuhrman JA, Hagström A, Azam F (1984) Bacterioplankton growth in seawater: I. Growth kinetics and cellular characteristics in seawater cultures. Mar Ecol Prog Ser 18:31-39

Azam F, Fenchel T, Field JG, Gray JS, Meyer-Reil LA, Thingstad F (1983) The ecological role of water-column microbes in the sea. Mar Ecol Prog Ser 10:257-263

Cadée GC, Hegeman J (1979) Phytoplankton primary production, chlorophyll and composition in an inlet of the Western Wadden Sea (Marsdiep). Neth J Sea Res 13: $224-241$

Choi JW, Sherr EB, Sherr BF (1996) Relation between presence-absence of a visible nucleoid and metabolic activity in bacterioplankton cells. Limnol Oceanogr 41:1161-1168

Douglas DJ, Novitsky JA, Fournier RO (1987) Microautoradiography-based enumeration of bacteria with estimates of thymidine-specific growth and production rates. Mar Ecol Prog Ser 36:91-99

Grossmann S (1994) Bacterial activity in sea ice and open water of the Weddell Sea, Antarctica: a microautoradiographic study. Microb Ecol 28:1-18

Gundersen K, Bratbak G. Heldal M (1996) Factors influencing the loss of bacteria in preserved seawater samples. Mar Ecol Prog Ser 137:305-310

Heissenberger A, Leppard GG. Herndl GJ (1996) Relationship between the intracellular integrity and the morpho-

Editorial responsibility: John Dolan,

Villefranche-sur-Mer, France logy of the capsular envelope in attached and free-living marine bacteria. Appl Environ Microbiol 62:4521-4528

Hobbie JE, Daley RJ, Jasper S (1977) Use of Nuclepore filters for counting bacteria by epifluorescence microscopy. Appl Environ Microbiol 33:1225-1228

Hoppe HG (1977) Analysis of actively metabolizing bacterial populations. In: Rheinheimer G (ed) Microbial ecology of a brackish water environment. Springer-Verlag, Berlin, p $179-197$

Hoppe HG (1978) Relations between active bacteria and heterotrophic potential in the sea. Neth J Sea Res 13:78-98

Karner M, Fuhrman JA (1997) Determination of active marine bacterioplankton: a comparison of universal $16 \mathrm{~S}$ rRNA probes, autoradiography, and nucleoid staining. Appl Environ Microbiol 63:1208-1213

Meyer-Reil LA (1978) Autoradiography and epifluorescence microscopy combined for the determination of number and spectrum of actively metabolizing bacteria in natural waters. Appl Environ Microbiol 36:506-512

Porter J, Diaper J, Edwards C, Pickup R (1995) Direct measurements of natural planktonic bacterial community viability by flow cytometry. Appl Environ Microbiol 61: 2783-2786

Porter KG, Feig YS (1980) The use of DAPI for identifying and counting aquatic microflora. Limnol Oceanogr 25:943-948

Posch T, Pernthaler J, Afreider A, Psenner R (1997) Cell-specific respiratory activity of aquatic bacteria studied with the tetrazolium reduction method, Cyto-clear slides, and image analysis. Appl Environ Microbiol 63:867-873

Pyle BH, Broadaway SC, McFeters GA (1995) Factors affecting the determination of respiratory activity on the basis of cyanoditolyl tetrazolium chloride reduction with membrane filtration. Appl Environ Microbiol 61:4304-4309

Tabor PS, Neihof RA (1982) Improved method for determination of respiring individual microorganisms in natural waters. Appl Environ Microbiol 43:1249-1255

Turley CM, Hughes DJ (1.992) Effects of storage on direct estimates of bacterial numbers of preserved seawater samples. Deep Sea Res 39:375-394

Turley CM, Hughes DJ (1994) The effect of storage temperature on the enumeration of epifluorescence-detectable bacterial cells in preserved seawater. J Mar Biol Assoc UK $74: 259-262$

Zimmermann R, Iturriaga R, Becker-Birck J (1978) Simultaneous determination of the total number of aquatic bacteria and the number thereof involved in respiration. Appl Environ Microbiol 36:926-935

Zimmermann R, Meyer-Reil LA (1974) A new method for fluorescence staining of bacterial populations on membrane filters. Kieler Meeresforsch 30:24-27

Zweifel UL, Hagström $\AA$ (1995) Total counts of marine bacteria include a large fraction of non-nucleoid-containing bacteria (ghosts). A.ppl Environ Microbiol 61:2180-2185

Submitted: August 4, 1997; Accepted: October 13, 1997 Proofs received from author(s): January 19, 1998 